\title{
Seeking Full Citizenship: A Defense of Tenure Faculty Status for Librarians
}

\section{Catherine Coker, Wyoma vanDuinkerken, and Stephen Bales}

\begin{abstract}
Tenure status for library faculty in the academic environment is coming under increasing attack from administration, faculty members in other departments, and non-academics. This is due to incorrect perceptions about what academic librarians do and how they serve their profession. This paper describes the many challenges faculty librarians face in balancing their work load with service and scholarship; justifies why academic librarians need tenure; and ultimately proves that tenure and faculty status for academic librarians are an absolute necessity.
\end{abstract}

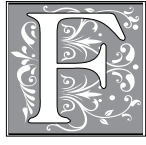

aculty status and tenure for librarians in the academic environment has been debated for over a hundred years. Tenure for librarians was suggested as early as 1911, but it was not officially endorsed until $1946 .{ }^{1}$ In the early 1970 s, most universities as well as library and teaching faculty organizations acknowledged the high quality and essential work performed by academic librarians, and so they began supporting and granting librarians with academic or faculty status. An example of this support is the 1973 American Association of University Professors (AAUP) Statement on Faculty Status of College and University Librarians. The AAUP created this statement, which called for academic universities to grant faculty status to librarians, together with the Association of American Colleges and Universities (AACU) and the Association of College and Research Libraries (ACRL). ${ }^{2}$ These groups recognized how the academic librarianship had changed over the years and how academic librarians had applied professional standards and academic rigor comparable to teaching faculty. However, the majority of academic librarians are not "teaching faculty" and do little if any teaching in the traditional sense. This "teaching vs. nonteaching" difference has resulted in a problem for academic administrators when they try to apply the same promotion and tenure standards to both librarians and teaching faculty.

\section{Literature Review}

\section{What Are Academic Librarians and What} Do They Do?

For if Librarie-keepers did understand themselvs in the nature of their work, and would make themselvs as they ought to bee, useful in their places in a publick waie; they ought to becom Agents for the

Catherine Coker, Wyoma vanDuinkerken, and Stephen Bales are Assistant Professors at Texas A E M University Libraries; e-mail: ccoker@lib-gw.tamu.edu,wvanduin@lib-gw.tamu.edu, sbales@lib-gw.tamu. edu. (C) Catherine Coker, Wyoma vanDuinkerken, and Stephen Bales 
advancement of universal Learning: and to this effect I could wish, that their places might not bee made as everie where they are, Mercenarie, but rather Honorarie (John Durie, 1650). ${ }^{3}$

Although librarianship has existed for thousands of years, the character of academic librarianship has changed dramatically over the past century. This evolution of professional identity has not been an easy process, but neither is it unique. Other professions, including the teaching professoriate, have gone through similar redefinitions of function during the modern era (for instance, college professors shifted their focus from primarily instruction to research). Academic librarianship, in the modern sense, is still a comparatively young and misunderstood profession.

The late-nineteenth century move from the liberal arts model of education to the university model, and the increased focus on the production of primary research at the university, elevated the importance of the library and the visibility (if not status) of the librarian. ${ }^{4}$ The increasingly centralized role of the library in higher education saw the need for trained librarians, beginning with Melvil Dewey's program at Columbia University. This was followed by exponential growth of information after World War II, requiring the further development of specialized academics - librarians - to manage an enormous increase in documents. ${ }^{5}$ Academic librarians were also needed to educate the massive postwar influx of undergraduates on how to locate and use these documents (college enrollment jumped from 2,300,000 to 8,650,000 from 1950 to 1970 alone). ${ }^{6}$ Where being a librarian had once been a part-time or temporary job for faculty members, students, or even janitors, all of whom were essentially "caretakers of books," it had become increasingly professionalized. ${ }^{7}$

In the twentieth century, Library and Information Science (LIS) emerged as a scholarly discipline, and academic librarians, while differing from their "teaching faculty" counterparts in certain aspects, had become recognizable as a species of the same genus: academic professional. This professionalization and functional alignment with scholarship and education was marked by the publication of a code of professional ethics, ${ }^{8}$ the establishment of LIS doctoral programs, and the requirement of the master's degree for librarians. ${ }^{9}$ The modern profession of academic librarianship, however, is still in the midst of birthing pangs and in need of clear direction and definition.

John-Bauer Graham defined the modern academic librarian as, at her simplest, "an individual possessing a Master's in Library Science (or equivalent degree) and working in a college or university library or library system." ${ }^{\prime 10}$ This is a deceptively simple description, however, and Graham goes on to describe academic librarians as being simultaneously "university employees, teachers, professionals, clerical staff, support staff, professors, administrators, [and] public servants."11 Academic librarians support the educational and research requirements of the faculties and students and engage in both education (either indirectly or directly) and original research, all the while actively administering the entity of the library (both internally and as it relates to wider educational institution). Certainly, the particular professional practice of individual librarians may differ considerably (that is to say, librarians may be professional catalogers, reference librarians, serials librarians, bibliographers, and so on), but all dedicated academic librarians are information scientists practicing as scholars and educators in a dynamic laboratory (the academic library). ${ }^{12}$ Academic librarians, like all faculty members, are what they do: in other words, they profess their calling through action, and the best librarians make great "contributions to learning and scholarship-which is, after all, what our colleges and universities are about."13 
Many scholars argue against this concept of academic librarian as "teacher-scholar." They claim that academic librarians do not fit the traditional (read: conservative, stereotypical) model of teaching faculty and are ill suited for full faculty status. True, academic librarians do not often "teach," at least in the manner typically attributed to teaching faculty, nor are librarians required to obtain the $\mathrm{PhD}$ for employment (leading to the conclusion that they must play catch-up in research or their research is of lower quality). Librarians do, nonetheless, fit the faculty model, if one is willing to allow for a broad definition of academia in terms of the basic functions of educating, researching, and administering, and possibly they extend the concept of "service" in some cases. ${ }^{14}$ Janet Swan Hill noted that librarianship relates to the "faculty model" in that the profession is (1) a distinct academic discipline, and that (2) academic librarians engage in intellectual work, (3) serve the community, (4) engage in (albeit primarily applied) research, (5) collaborate in scholarship, (6) cooperate in developing disciplinary standards, (7) actively practice in a profession (that is, librarianship as equivalent to teaching), and (8) administer their domain (the library). ${ }^{15}$

Academic librarians are on the cutting edge of academia in the postindustrial world. They educate and practice both applied and original scholarship. They facilitate access to information and seek to better understand information in relation to its users. The postindustrial world, unfortunately, has as yet failed to provide academic librarians with the necessary status to realize their professional potential. Full citizenship within the academic community at large is necessary to accomplish this task.

\section{Policy Statements}

The second half of the twentieth century saw a push toward the adoption of faculty status for academic librarians. ${ }^{16}$ This shift was largely due to the ongoing profes- sionalization of academic librarianship and the subsequent recognition of the relationship between elevated professional status and effectiveness in the discipline. It also reflected the comparatively recent move in academia toward primary research and the resulting magnification of the importance of research libraries. ${ }^{17}$

In 1940 the American Association of University Professors (AAUP) and the Association of American Colleges (AAC) (later renamed the Association of American Colleges and Universities) published its 1940 Statement of Principles on Academic Freedom and Tenure. This document "laid the groundwork for the modern concept of tenure." 18

The 1940 Statement of Principles defines tenure as "a means to certain ends; specifically: (1) freedom of teaching and research and of extramural activities, and (2) a sufficient degree of economic security to make the profession attractive to men and women of ability."19 The document is vague in terms of specifics concerning status and tenure, perhaps purposefully so. It outlines the requirements for tenure as including any person teaching a full-time load, but it does not define the exact nature of the "teaching" or the specific academic credentials necessary for "teaching." This nonspecificity left room for debate concerning the legitimacy of the "teaching" performed by academic librarians.

It may be argued that the 1940 Statement's authors were purposefully less rigid in their concept of instruction (Trower pointed out that academic freedom statements seldom define "faculty"). ${ }^{20}$ The term "teacher," in fact, "is understood [in the Statement] to include the investigator who is attached to an academic institution without teaching duties." ${ }^{21}$ The 1940 Statement, furthermore, makes no interpretations concerning what qualifies as "research" and extends no preeminence to either theoretical or practitioner investigation. In view of these observations, it is no surprise that both the AAUP and the AAC would later side with academic 
librarians in their fight for faculty status and tenure. The American Library Association (ALA) was, in fact, the third of 209 organizations to endorse the document (doing so in 1946). This suggests that, while misunderstandings certainly exist between "teaching faculty" and academic librarians concerning role and function, a basic shared understanding of education, academic exploration, and the need for intellectual freedom existed between teaching faculty and academic librarians during a seminal period in the development of higher education in the United States.

The ACRL, a division of ALA, has long been "dedicated to enhancing the ability of academic library and information professionals to serve the information needs of the higher education community and to improve learning, teaching, and research." 22 The association, in contrast to its parent organization the $\mathrm{ALA},{ }^{23}$ has served as a leader in the effort toward realizing the 1940 Statement of Principles' resolutions for academic librarians.

In 1959, the ACRL's Committee on Academic Status of its University Libraries Section released a report entitled The Status of College and University Librarians. The document notes multiple reasons for giving academic librarians faculty status, including the increasing demands on librarians as educators, advances in librarianship as a defined field, and the necessity of academic freedom protections for practitioners. ${ }^{24}$ Following this report (and a period of woodshedding during the 1960s), ${ }^{25}$ ACRL has consistently vocally supported faculty status for college and university librarians through published statements. The association articulated basic standards for faculty status in its ACRL Standards for Faculty Status for College and University Librarians, formally adopted in 1971, with the latest version approved in 2007. ${ }^{26}$ This formal statement of purpose establishes librarians as "partners" with teaching faculty, claiming an equivalency between librarians and teaching faculty in terms of both research and teaching contributions. The $A C R L$ Standards urges colleges and universities to adopt a set of standards concerning librarians that would provide them with faculty status: (1) that faculty librarians are to be evaluated in their responsibilities by their peers, (2) that they share in both library and (3) college and university governance, (4) that they be paid comparably to teaching faculty, (5) that librarians "be covered by a stated tenure policy," (6) that they be promoted consistently with established standards, (7) that they be made eligible for sabbaticals and research funds, and (8) that librarians be provided with academic freedom commensurate to teaching faculty. ${ }^{27}$

These standards were followed by the 1972 ACRL Joint Statement on Faculty Status of College and University Librarians, which further portrayed librarians as legitimate beneficiaries of the 1940 Statement of Principles. The Joint Statement was drafted as a joint effort by the ACRL, $\mathrm{AAC}$, and the AAUP. It asserts that academic librarians play a key role in the learning process and that faculty status should be granted as a result of functional identity (that is, professional engagement in research and teaching). The document states that academic librarians, similar to traditional teaching faculty, perform both a teaching role and a research role and should be thus eligible for faculty status:

...[academic librarians] instruct students formally and informally and advise and assist faculty in their scholarly pursuits. Librarians are also themselves involved in the research function; many conduct research in their own professional interests and in the discharge of their duties. ${ }^{28}$

College and university librarians, therefore, are entitled to the same rights as other faculty, including "corresponding entitlement to rank, promotion, tenure, compensation, leaves, and research funds," as well as the ability to share 
in institutional governance. ${ }^{29}$ The Joint Statement was last reaffirmed (without changes) in 2007.

This impetus for the establishment of faculty status for academic librarianship has not slowed since the early 1970s, and ACRL remains at the vanguard of the movement. Further policy statements have been approved by the ACRL to bring academic librarianship into line with the tenure model. The Guideline for the Screening and Appointment of Academic Librarians Using a Search Committee outlines a model for shared departmental responsibility in hiring. ${ }^{30}$ The ACRL Guideline on Collective Bargaining states that librarians should be included with teaching faculty in terms of collective bargaining. ${ }^{31}$ Recently, a Guideline for the Appointment, Promotion, and Tenure of Academic Librarians was approved that outlines procedures for "application within the context of two ACRL policy statements [the 1971 Standards and 1972 Joint Statement] on faculty status for academic librarians, as well as related statements issued by the American Association of University Professors." ${ }^{\prime 2}$

In 2009, June Garner, Karen Davidson, and Becky Schwartzkopf published an essay discussing the most recent iterations of the tenure process for librarians. ${ }^{33}$ The results show that most institutions require a second advanced degree to be eligible for a tenure-track position; that a wide variety of activities-grants, refereed articles, book chapters, conference proceedings and poster sessions-were accepted as scholarly contributions. What was interesting about this essay was that it stated that teaching faculty have a distinct advantage over library faculty with regard to open summers available for research. Although this supports the belief that academic librarians are faced with increasing expectations, it is important to remember that, as the bar rises, both their respect as faculty members and their salary remain low compared to teaching faculty members in academic institutions.

Although the preceding organizational statements suggest that there has been some progress made in the elevation of academic librarianship, this shift has been neither profound nor universal, and it is mired in perpetual debate. Much of this torpor may be blamed on librarianship's weak professional standing at the beginning of the nineteenth century, conservative institutional bureaucracies, quality control issues concerning library education, and the nagging presence of teaching faculty disregard for, or misunderstanding of, librarianship. ${ }^{34}$ This final sticking point is possibly the most frustrating obstacle to overcome (especially considering the official partnering of the two camps' professional associations). Librarians must be vocal in defending their academic citizenship, for

we must be able to think freely and independently, to test our practices and procedures, and to integrate our activities with the other instructional and research functions in our institutions. We have the responsibility to insist on the autonomy to do our jobs properly if we are indeed to be able to give the best service to our institutions. ${ }^{35}$

At Texas A\&M University College Station (TAMU), the foundation that the promotion and tenure guidelines rest on is the customary teaching, scholarship, and service model. Since librarians do not teach in the traditional sense, adaptations of promotion and tenure standards for librarians were created to evaluate librarians' contributions appropriately. For librarians, the foundation that the promotion and tenure guidelines rest on is the librarianship, scholarship, and service model. ${ }^{36}$ Although great debate surrounds this question, for the purpose of this paper we define librarianship as:

the profession practiced by those who work in libraries. The principal focus of the work of the librarian is on services to library users, but this manifests itself in many ways. 
It includes the selection, cataloging and arrangement of books and other documents and information resources in all media and format; the provision of services to answer the queries of users, including giving access to information resources that are not held in the library; and the management and administration of these processes and of the library itself. ${ }^{37}$

The shift away from teaching to librarianship has caused a continuous debate in the academic community over the issue of faculty status for librarians. The reason for the debate rests on the fact that few teaching faculty and university administrators understand what "librarianship" entails. Consequently, as Hill suggested, we as librarians have been continuously forced to communicate and defend academic tenure for librarians. Librarians must communicate that librarianship "has its own foundations and theory and practice, its own ethical constructs, its own literature and its own type of academic preparation" and as a result must be evaluated against benchmarks appropriate to the discipline. ${ }^{38}$ Although we cite the need of academic freedom as an argument, this response does not fully communicate what academic tenure for librarians mean to the academic community.

\section{What Is Tenure and How Is It Attained?}

According to the American Association of University Professors, tenure is "an arrangement whereby faculty members, after successful completion of a period of probationary service, can be dismissed only for adequate cause or other possible circumstances and only after a hearing before a faculty committee." ${ }^{\prime 39}$ For librarians, tenure shall be available to them in accordance with the tenure provisions of all faulty of the institution. ${ }^{40}$ What this means is a librarian, like any other teaching faculty, who is hired under a tenure-track position must go through a demanding selection and approval pro- cess that usually takes their entire career. It begins with a competitive national and international search. Once hired, the tenure candidate will be on a "tenure track" (that is, a probationary tenure term). The length of this term and the actual "tenure clock" by which an institution measures the candidate's progress varies from institution to institution, though here we will use TAMU's system as our example. ${ }^{41}$ For the tenure-track librarian, librarianship, research, and service are reviewed each year by library administration. If on the third year the librarian does not show promise as a tenure-track faculty member, he or she is asked to leave. However, if the librarian passes the third-year review, it is not until the seventh year that he or she will "go up for tenure." During this seventh year, the candidate's librarianship performance, research, and service activities are carefully reviewed by the tenured library faculty as well as various outside university administrators ranging from the Dean of Faculties, University Provost, President of the University (and Chancellor and Regents here at TAMU). Success for the faculty member is measured by the obtaining of tenure of promotion to a higher rank. In the initial promotion from Assistant to Associate Professor, here at TAMU, the candidate is continually faced with "post tenure review" each year. Should a librarian fail three years in a row to meet the job requirement, he or she is placed on review and could possibly be terminated.

\section{What Advantages Are There for Retaining Tenure for Librarians?}

The primary protection that tenure gives all tenured faculty members is academic freedom, though there are other protections that we will examine in more detail. Academic freedom gives tenure-track faculty members the freedom to voice opinions and publish in areas where they are trained and without the fear of dismissal for going against what university administration and/or certain segments of society agree with. However, as stated 
above, the foundation of a librarian's job responsibilities rests on benefiting library users to meet their needs, and this is often manifested in the term and duties of librarianship. This includes "the selection, cataloging and arrangement of books and other documents and information resources in all media and format; the provision of services to answer the queries of users, including giving access to information resources that are not held in the library; and the management and administration of these processes and of the library itself." ${ }^{42}$ However, if a librarian's academic freedom is not protected, then, like teaching faculty, he or she might give a guarded and abridged version of the thoughts and ideas in his or her research. In addition, librarians will also guard against purchasing and disseminating controversial informational resources to help answer users' questions, under the threat that their jobs are not adequately protected. This would limit the influx of new ideas coming into the university environment and stifle the development of knowledge.

\section{Arguments Against Faculty Status for Librarians}

There are often arguments from within the profession that tenured librarians tend to become unproductive, that they put their feet up and stop working. This is a fallacy. Although librarians may certainly abuse tenure, one must remember that there are unproductive people among the teaching faculty and in the corporate environment as well. Librarians in academia who are not performing are the exception and not the rule. According to Hohm and Shore:

"More common is the situation where, as professors mature, they place less emphasis on front-line research and more emphasis on teaching and university service. Tenure gives them the freedom to devote their time to teaching and university service, without fear that some younger person will publish more and take their job away. Also, governance is- sues require knowledge and experience which younger faculty may not have acquired. The senior faculty is often expected to carry the burden in this area." ${ }^{43}$ For purposes of this paper, we define "university service" as those academic committees, work groups, and otherwise compulsory or heavily encouraged attendance at university events that take up large amounts of effort and time up and away from librarianship, research, and teaching. This is demonstrated at TAMU when librarians move from Associate Professor to Full Professor status. There is a greater emphasis on service moving to Full than there was moving to Associate.

Richard M. Dougherty, ${ }^{44}$ Davey and Andrews,${ }^{45}$ and Blaise Cronin, ${ }^{46}$ along with others argued that librarians should not be tenured faculty because their terminal degree of Master of Library Science (MLS) does not prepare them to perform the necessary scholarly research required of a tenured professor. Cynthia Tysick and Nancy Babb stated that, although many MLS degree programs require their students to take research methodology classes, few have writing classes that prepare their students for the scholarly roles in academic profession. ${ }^{47}$ However, the same lack of training might be said about most $\mathrm{PhD}$ programs for teaching faculty. Most academic institutions view teaching as its primary mission, ${ }^{48}$ and as a result researchers have recognized that formal PhD education has failed to prepare academic professors with the proper teaching skills needed to teach classes. ${ }^{49}$ Consequently, unlike librarians who have the practical training to perform the librarianship portion of their job, teaching faculty struggle to perform the practical side of their job: teaching. Both librarians and teaching faculty, therefore, face similar problems when starting the tenure process.

Since many believe that tenuretrack librarians are unable to perform these scholarly responsibilities, it is also believed that the scholarly responsibilities required to gain tenure 
is the primary reason for turnover in academic libraries. However, Elizabeth C. Henry, Dana M. Caudle, and Paula Sullenger proved this to be false. ${ }^{50}$ They researched the effect of tenure on retention in academic libraries and discovered that tenure had little if any effect on turnover. These and other authors point to evidence of librarians' enthusiasm for scholarship..$^{51}$ Examples of evidence can be found in table 1 below, which examines 379 libraries in the United States and ranks them according to scholarly production.

As the above table shows, university librarians publish heavily-often publishing in numbers comparable to the teaching faculty. In addition, following John M. Budd's research regarding the publishing trends of university faculty, we can also extrapolate that those library faculty publishing most actively are those on the tenure track. ${ }^{52}$ We might further conclude that, with the loss of tenure, the librarianship profession as a whole will lose invaluable research to universities trying to save a handful of dollars in these hard times.

In fact, it is the quasi-status of librarians not being tenured that causes turnover in tenure-track libraries. John H. Moriarty stated that, if true faculty status is withheld, the consequences to the profession would be dire: ${ }^{53}$

\begin{tabular}{|c|c|c|c|}
\hline \multicolumn{4}{|c|}{$\begin{array}{c}\text { TABLE 1 } \\
\text { Most Productive Libraries, 1998-2002 (379 Libraries, } \\
\text { Ranked by Number of Authors) }^{54}\end{array}$} \\
\hline Institution & $\begin{array}{c}\text { Rank } \\
\text { (No. of } \\
\text { Authors) }\end{array}$ & $\begin{array}{l}\text { No. of } \\
\text { Articles }\end{array}$ & $\begin{array}{l}\text { Rank in Weller, } \\
\text { Hurd, Wiberley } \\
\text { (1999) }\end{array}$ \\
\hline Texas A\&M University & $1(45)$ & 41 & 9 \\
\hline Pennsylvania State University & $2(39)$ & 38 & 1 \\
\hline University of Illinois at Chicago & $3(31)$ & 35 & 5 \\
\hline University of Illinois at Urbana-Champaign & $4(28)$ & 42 & 3 \\
\hline Ohio State University & $61(26)$ & 38 & 7 \\
\hline Iowa State University & $6(26)$ & 19 & 6 \\
\hline University of Michigan & $8(20)$ & 18 & 11 \\
\hline Cornell University & $8(20)$ & 20 & 2 \\
\hline University of Florida & $8(20)$ & 12 & 10 \\
\hline University of Iowa & $10(19)$ & 12 & - \\
\hline University of New Mexico & $11(18)$ & 21 & 14 \\
\hline Purdue University & $11(18)$ & 21 & - \\
\hline Vanderbilt University & $11(18)$ & 9 & - \\
\hline Yale University & $149(17)$ & 19 & - \\
\hline University at Albany & $14(17)$ & 17 & 15 \\
\hline University of Pittsburgh & $14(17)$ & 12 & - \\
\hline University of Colorado-Boulder & $17(16)$ & 15 & 18 \\
\hline Colorado State University & $17(16)$ & 13 & - \\
\hline Indiana University & $19(15)$ & 16 & - \\
\hline University at Buffalo & $19(15)$ & 14 & - \\
\hline
\end{tabular}


Present practitioners must ask for unequivocal status for such professors or we will never be able to recruit the quality of people required [...] we should never settle for "with the rank of" or for "Librarians Grade I" or VI or higher. Twenty-five years in the academic world has taught me that lesson. If you do, then some young and new business manager does not understand, and a librarian rated as Librarian III does not get a travel grant reserved for professors. Or a new president comes to office and appoints a campus-wide committee for some key purpose and forgets to name any librarian member. The oversights, the "pin-pricks" brought on by any quasi-status are pointlessly but cruelly demeaning, they sour able people, they make present librarians only halfhearted recruiters of new professionals, or, as in the past, they drive able librarians out of the profession. ${ }^{55}$

Not only is communicating what librarianship is to academic administrators essential for librarians to retain their tenure status, it is also important to communicate how tenure-track librarians evaluate their scholarly publications for promotion and tenure so university administration may see that academic librarians have similar publication criteria as the rest of the teaching faculty. Such communication is important; since administration often does not fully understand what librarianship is, they rely heavily on something they do understand: publications. Park and Riggs' 1989 survey revealed that university administrators are more likely to review academic librarians' tenure packets on the basis of publication record, as opposed to service and job performance.

Like teaching faculty, journal articles and monographs are the two most customary types of publications written by academic librarians. ${ }^{56}$ There are numerous articles that mention a number of criteria for evaluating scholarly publications for librarians. The simplest criteria are articles appearing in refereed journals. ${ }^{57}$ Miller examined other criteria such as: number of refereed publications, assessments by peers, and citation counts. However, in 1995 the quantity of publications was discarded in lieu of quality of research when College $\mathcal{E}$ Research Libraries called for the quality of research to be evaluated according to its place of publication. ${ }^{58}$ As stated above, the primary merit upon which a publication rests is if the journal is peer reviewed. However, the evaluation of journal quality points beyond just peer review. Other important factors include the following: the reputation of the editor and the editorial review board, the inclusion of the journal in citation indices, the opinions of leading researchers, the journal's appearance in ranking lists, its citation impact factor, the opinions of colleagues in the same or similar research field, the journal's longevity, its acceptance rates, and its circulation (in other words, the number of subscribers). ${ }^{59}$

\section{The Importance of Faculty Status}

The ACRL Joint Statement on Faculty Status of College and University Librarians states that "the function of the librarian as participant in the processes of teaching and research is the essential criterion of faculty status." ${ }^{\prime 60}$ These additional expectations for academic librarians set them aside from most other types of librarians, who generally do not have research expectations, and for whom publications are a special achievement rather than de rigueur. Faculty librarians provide much of the scholarship in librarianship as a method of sharing knowledge with the profession. Librarians in public libraries, $\mathrm{K}-12$ schools, and other institutions also contribute to professional publications, but the brunt of quantitative and methodological research in the field falls to faculty-rank librarians.

Faculty status offers librarians a series of protections both tangible and psychological. A faculty librarian is permitted to 
use work time to attend and participate in professional conferences such as those held by ALA and ACRL; to conduct and publish research and share it with peers; and the academic freedom to teach and advance scholarship through research. Nonfaculty librarians often cannot do these things or can do so only on a limited basis. For instance, numerous meetings at ALA-sponsored conferences are held over weekends to accommodate librarians who can only participate during that time because they have to request leave for the additional days. In other fields, weekends would be used for conferences only as built-in travel time for participants. Nonfaculty librarians also seldom have the time or resources for research and publication, and teaching is limited to the aims of the institution rather than the librarian's purview.

Psychologically, faculty status protects librarians from those patrons who inflict their temper and beliefs on libraries. There is nothing more upsetting to a librarian than being pressured by a library patron because the librarian purchased a book for the library collection that went against the patron's belief. A perfect example of this was when Jeanne Layton, the Davis County librarian, was pressured by the Davis County Commission and its library board to remove the controversial novel Americana written by Don DeLillo from the library's shelves. When the librarian stood her ground, she was fired. ${ }^{61}$ Although this example took place in 1979, it is a perfect example of what pressures librarians face even today. It is not uncommon for a library patron to request to speak to the librarian's supervisor, often the Dean of Academic Libraries, to complain about the perceived inappropriate book.

\section{Academic Librarians and Teaching Faculty}

Superficially, tenure-track academic librarians appear to be a breed apart from tenure-track faculty in other departments. Often, the publishing and service requirements for tenure are lower for librarians than for other tenure faculty. This is not because of a lack of academic rigor, but rather because of a lack of time and funding. Most librarian appointments are for a twelve-month period, rather than the nine months that is more typical for other faculty. Hill equates the time required to perform daily job functions, participate on special projects, and other necessary activities to what would equate to a heavy teaching load for other faculty. ${ }^{62}$ In addition, librarians remain busy even when the students have gone home. Class intersession periods-the weeks from the end of finals to the first day of the new semester-are also the busiest periods for librarians working behind the scenes. This is when it is possible to update and perform maintenance on electronic resources, when new personnel can be interviewed and hired, and when new programs are readied to roll out for the public.

Librarians are also required to be reactive to current events and special circumstances, such as being required to work holidays and during times of crisis, because by doing so they are providing continuing services to others. Large campus libraries are frequently open for several hours on such holidays as New Year's Day, Easter, and Memorial Day. When hurricanes hit, librarians are at home with their computers answering reference questions until the power goes out. (And yes, just because there is a weather emergency-or any other emergencythe questions keep coming in.) When the H1/N1 virus broke out in early 2009, Web sites with numerous links to health and safety resources popped up almost immediately on library pages across the United States and Canada.

Librarians also spend a great deal of time on continuing their education and improving their supervisory skills. Unlike teaching faculty, it is not uncommon for tenure-track librarians to supervise departments that have both tenured librarians and staff members report- 
ing to them. On top of the additional supervisory training we are required to take, we also continually follow new technology trends-Web 2.0, gaming as literacy, a dozen software programs - to stay abreast of new information technology trends so that we can make them available for the library's users. For specialists, other skills such as paleography, bookbinding, digitization, or metadata creation need constant enhancement. Attending at least one class or workshop a year is almost mandatory for many academic librarians.

Last, librarians must be unusually prepared on a number of fronts. It is not at all unusual for a librarian's job specifications or title to change significantly. For instance, an English literature faculty member working on a Chaucer commentary will never be transferred to the Aerospace Engineering Department and told to teach structural analysis or write a paper on propulsion methods. However, in library departments it is not uncommon for someone to be moved from public service to acquisitions and cataloging, or from archives to digital projects. Due to the time it takes to learn the librarian's new job responsibilities, he or she is faced with less time to perform research; and, since most research done by librarians revolves around their job responsibilities, their research suffers. This is supported in the 1999 survey results of Pennsylvania academic libraries when they discovered that approximately 60 percent of librarians' peer-reviewed journals were published in the area of their subject expertise rather than those in the context of librarianship. ${ }^{63}$ Nevertheless, the tenure clock ticks on, and librarians are expected to publish regularly in peer-reviewed journals regardless of the learning curves they find themselves behind when they are transferred to a new department.

\section{Academic Freedom}

Tenure, in many cases, was developed and maintained as a series of protections for faculty, including but not limited to protecting academic freedom. Jerry D. Campbell stated that librarians don't need this freedom because it "is not the nature of our business. We are not the explorers or the teachers." 64 This is a misguided statement. Librarians are frequently the explorers of new technologies, sharing what they learn with their patrons. Librarians are also teachers, not just in the area of their specialization but in the new domain of information literacy. This role also encompasses instruction on the dangers of copyright infringement, intellectual property rights, and academic integrity and plagiarism. Gail Wood acknowledged the important role librarians play in these battles, noting that librarians' bibliographic instruction aids in "developing a strong expressive voice in the student-scholar, one who uses information wisely and appropriately in support of original ideas." 65

The roles of explorer and teacher are not limited to librarians in higher education. Librarians from public, corporate, and other educational venues share common goals in ensuring that patrons have access to information as well as privacy protections. In some cases, this involves fighting bans on books, Web sites, or unmonitored Web access. In the past decade, such incidents have received wide media exposure through online editions of newspapers, Web broadcasts of news videos, and television. In the wake of these cases, librarians from all sectors have published items in library periodicals and journals to share what they learned from these incidents, such as recommending courses of action for handling ban requests or how to make the best of media attention.

Academic freedom is thus an important issue for librarians, as well as for librarians facing the tenure process. Librarians researching free speech issues, technological issues, or even copyright issues often take stands that others disagree with. Michelle Martinez, a reference librarian, wrote in an essay her response 
to a patron offended by a work of erotic literature:

In the process of discussing the book challenge of Apollinaire's Eleven Thousand Rods with my colleagues, I declared that I would become the Dirty Librarian: the librarian who ordered erotic fiction, classical, modern, and otherwise for my personal collection; the librarian who would also read said items and be able to converse intelligently upon them (and I do blog on occasion), and perhaps the librarian who would make a career of writing about and discussing pornography and erotica. ${ }^{66}$

In some fields such a declaration would be controversial. In the library science field, this declaration is accepted. It has always been the duty of conscientious librarians to defend controversial literature. In the twenty-first century, librarians also find themselves defending access to controversial Web sites or information and fighting those who wish to restrict others' access to information.

\section{Conclusions}

As can be seen from the evidence presented thus far, library faculty members are on par with teaching faculty members in regard to scholarship and service. As such, librarians require the protections offered by tenure to continue contributing to their profession without administrative repercussions should a librarian choose to publish or teach on controversial topics. Faculty librarians provide valuable contributions to scholarship both in LIS-oriented journals and in the journals of their subject specialty. These contributions to scholarship and to the profession should not be diminished but encouraged.

\section{Why Librarians Should Be Concerned}

Unfortunately, due to economic trends, many librarians are facing budgetary and personnel cuts. Some administrations ask why librarians should hold tenured faculty status when it would be easier to hire shelving assistants and keep only a professional or two around. This outlook is naïve at best and detrimental to the institution at worst. Gail Gilbert describes how the University of Louisville's librarians' faculty status was removed for six years. ${ }^{67}$ The institution's President had envisioned money saved, improved staffing, and increased flexibility; the question of what this had to do with faculty status was never answered. The library maintained its high standards and, with a new administration, restored faculty status thirteen years later. The Kentucky librarians' story is one of both caution and hope. It shows that determined librarians can successfully fight hostile administrations.

\section{Steps to Take}

If you share the conviction that academic librarians are not clerks but scholars, and thus deserving of full academic citizenship, consider the following:

1. Organizing Effectively: Become politically active through savvy organization. According to the AAUP's Statement on Collective Bargaining, collective bargaining should (1) "protect and promote the professional and economic interests of the faculty as a whole," (2) "maintain and enhance" representative faculty governance, (3) "obtain explicit guarantees of academic freedom and tenure," and (4) "create orderly and clearly defined procedures for prompt consideration of problems and grievances." ${ }^{68}$ Identify and join your local AAUP chapter. If there is not one, organize one.

2. Educating Constantly: Educate your teaching faculty colleagues, whether they consider you a colleague (yet) or not, as to the integral role of the librarian within the larger academic community. Convince them of the necessity of the tenured librarian for their academic freedom and the need for librarians' investiture with full status and academic freedom to fulfill this role. Take steps to continuously educate 
yourself as well. Understanding your role as an academic is the only way to function properly as an academic and library professional.

3. Participating Actively: The previous steps may only be accomplished through consistent engagement in the life of the college or university. The library is not a building alone, and the fact that librarians are so much identified with the building unfairly isolates them. Jane Forgotson, paraphrasing Heinrich Heine, wrote that "the professor loves librarians like his grandmother-there's always a little room for them behind the stove." ${ }^{69}$ So venture outside the library walls: join outside committees and "nonlibrary" academic associations. Both demand and prove your right to academic citizenship.
Too often, we librarians are at fault for being overly self-effacing in our work. We will insist that we do not teach despite regularly holding dozens of instruction sessions. We are modest in publicizing our research. To gain recognition as full citizens in academia, we need to take control, and protecting our tenure status is a major part of that control. In these troubled times, we should take the advice of the AAUP:

\section{It follows that the renunciation} of tenure, or of the ability to be a candidate for tenure, is not merely a private exchange; it has much larger institutional and social consequences. Such an offer to relinquish tenure or not to be considered for tenure ought not only be refused, it ought not be made. ${ }^{70}$

\section{Notes}

1. Virgil F. Massman, Faculty Status for Librarians (Metuchen, N.J.: Scarecrow, 1972), 97-102.

2. Nancy Davey and Theodora Andrews, "Implications of Faculty Status for University Librarians, with Special Attention to Tenure," The Journal of Academic Librarianship 4, no. 2 (1978): 71-74.

3. John Dury, The Reformed Librarie-Keeper (1650) (Los Angeles: University of California, Los Angeles, 1983).

4. Richard E. Rubin, Foundations of Library and Information Science. 2nd ed. (New York: NealSchuman, 2004), 278-80.

5. Arthur A. McAnally, "Status of the University Librarian in the Academic Community," in Faculty Status for Academic Librarians: A History and Policy Statements (Chicago: American Library Association, 1975), 6.

6. George S. Bobinski, Libraries and Librarianship: Sixty Years of Challenge and Change, 1945-2005 (Lanham, Md.: Scarecrow Press, 2007), 41.

7. Orvin Lee Shiflett, Origins of American Academic Librarianship (Norwood, N.J.: Ablex Publishing, 1981), 48.

8. American Library Association, History of the Code of Ethics: 1939 Code of Ethics for Librarians. Available online at www.ala.org/Template.cfm?Section=History1\&Template=/ContentManagement/ContentDisplay.cfm\&ContentID=8875. [Accessed 23 June 2009].

9. Association of College and Research Libraries, Statement on the Terminal Professional Degree for Academic Librarians. Approved Jan. 23, 1975. Reaffirmed June 2001 and June 2007. Available online at www.ala.org/ala/mgrps/divs/acrl/standards/statementterminal.cfm. [Accessed 24 June 2009].

10. John-Bauer Graham, “What's in a Name?" Alabama Librarian 54, no. 1 (2004): 10-14.

11. Ibid., 10.

12. Janet Swan Hill, "Wearing Our Own Clothes: Librarians as Faculty," The Journal of Academic Librarianship 20, no. 2 (1994): 71-76.

13. Edward G. Holley, "Defining the Academic Librarian," College and Research Libraries 46, no. 6 (1985): 462-77.

14. Beverly J. Toy, "The Role of the Academic Librarian: A Symposium," Journal of Academic Librarianship 4, no. 3 (1978): 128-38.

15. Hill, "Wearing Our Own Clothes," 74-75.

16. John M. Budd, "Faculty Publishing Productivity: Comparisons Over Time," College and Research Libraries 67, no. 3 (2006): 230-39.

17. Shiflett, Origins of American Academic Librarianship, 48. 
18. Deborah Lee, "Faculty Status, Tenure, and Compensating Wage Differentials among Members of the Association of Research Libraries," Advances in Library Administration and Organization 26 (2008): 151-208.

19. AAUP \& AAC, 1940 Statement of Principles on Academic Freedom and Tenure, with 1970 Interpretive Comments. Approved in 1940. Changes adopted November 1989 and January 1990. Available online at www.aaup.org/nr/rdonlyres/ebb1b330-33d3-4a51-b534-cee0c7a90dab/0/1940statementofprinciplesonacademicfreedomandtenure.pdf. [Accessed 24 June 2009].

20. Cathy A. Trower, "What Is Current Policy?" in The Questions of Tenure, ed. Richard P. Chait (Cambridge, Mass.: Harvard University Press, 2002), 35.

21. AAUP \& AAC, 1940 Statement of Principles on Academic Freedom and Tenure. Available online at www.aaup.org/AAUP/pubsres/policydocs/contents/1940statement.htm. [Accessed 24 June 2009].

22. ACRL, What Is the Association of College and Research Libraries? Available online at www. ala.org/ala/mgrps/divs/acrl/about/whatisacrl/index.cfm. [Accessed 24 June 2009].

23. McAnally, "Status of the University Librarian," 4.

24. ACRL Committee on Academic Status, "Status of College and University Librarians," College and Research Libraries 20 (1959): 399-400.

25. McAnally, "Status of the University Librarian," 10.

26. ACRL, Association of College and Research Libraries Standards for Faculty Status for College and University Librarians. Approved 2007. Available online at www.ala.org/ala/mgrps/divs/acrl/ standards/standardsfaculty.cfm. [Accessed 24 June 2009].

27. Ibid.

28. ACRL, Joint Statement on Faculty Status of College and University Librarians. Approved June 26, 1972. Reaffirmed June 2001 and June 2007. Available online at www.ala.org/ala/mgrps/divs/ acrl/standards/jointstatementfaculty.cfm. [Accessed 24 June 2009].

29. Ibid.

30. ACRL, A Guideline for the Appointment, Promotion and Tenure of Academic Librarians. Approved June 2005. Available online at www.ala.org/ala/mgrps/divs/acrl/standards/promotiontenure.cfm. [Accessed 24 June 2009].

31. ACRL, Guideline on Collective Bargaining. Approved 1993. Reaffirmed 2008. Available online at www.ala.org/ala/mgrps/divs/acrl/standards/guidelinecollective.cfm. [Accessed 24 June 2009].

32. ACRL. A Guideline for the Appointment, Promotion and Tenure of Academic Librarians. Approved 2005. Web URL: < http://www.ala.org/ala/mgrps/divs/acrl/standards/promotiontenure. cfm>. [Accessed 24 June 2009.]

33. June Garner, Karen Davidson, and Becky Schwartzkopf, "Images of Academic Librarians: How Tenure-Track Librarians Portray Themselves in the Promotion and Tenure Process," The Serials Librarian 56, no. 1-4 (2009): 203-08.

34. McAnally, "Status of the University Librarian," 2-6.

35. Toy, "The Role of the Academic Librarian," 130.

36. Betsy Park and Robert Riggs, "Status of the Profession: A 1989 National Survey of Tenure and Promotion Policies for Academic Librarians," College and Research Libraries 52 (May 1991): 275-89.

37. John Feather and Paul Sturges, "Librarianship," International Encyclopedia of Information and Library Science. 2nd ed., ed. John Feather and Paul Sturges (London; New York: Routledge, 2003), 371.

38. Hill, “Wearing Our Own Clothes," 74-75.

39. American Association of University Professors, "Tenure." Available online at www.aaup. org/AAUP/issues/tenure/. [Accessed 15 June 2009].

40. Ibid.

41. More examples can be found in the survey by Garner, Davidson, and Schwartzkopf.

42. Feather and Sturges, "Librarianship."

43. Charles F. Hohm and Herbert B. Shore, "The Academic under Siege: Informing the Public about the Merits of Academic Tenure," Sociological Perspectives 41, no. 4 11998): 827-31.

44. Richard M. Dougherty, "Editorial: Faculty Status: Playing on a Tilted Field," Journal of Academic Librarianship 19, no. 2 (1993): 67.

45. Davey and Andrews, "Implications of Faculty Status for University Librarians."

46. Blaise Cronin, "The Mother of all Myths," Library Journal 126 no. 3 (Westport, Conn., 2001): 144.

47. Cynthia Tysick and Nancy Babb, “Writing Support for Junior Faculty Librarians: A Case Study," The Journal of Academic Librarianship 32, no. 1 (2006): 94-100.

48. David A. Dilts, Lawrence J. Haber, and Donna Bialik, Assessing What Professors Do: An Introduction to Academic Performance Appraisal in Higher Education (Westport, Conn.: Greenwood Press, 1994). 
49. Association of American Universities, AAU Graduate Committee Report, 1998. Available online at www.aau.edu/publications/reports.aspx?id=6900. [Accessed 25 June 2009].

50. Elizabeth C. Henry, Dana M. Caudle, and Paula Sullenger, "Tenure and Turnover in Academic Libraries," College and Research Libraries 55 (Sept. 1994): 429-35.

51. Dean R. Galloway, "The Three Faces of Axford: Or Blaming the Victim in Academia," Journal of Academic Librarianship 2, no. 6 (1977): 280-81; E.J. Josey, "Faculty Status Is Here to Stay," Journal of Academic Librarianship 2, no. 6 (1977): 282-83.

52. Budd, "Faculty Publishing Productivity."

53. John H. Moriarty, "Academic in Deed," College E Research Libraries 31 (1970): 14-17.

54. Stephen E. Wiberley Jr., Julie M. Hurd, and Ann C. Weller, "Publication Patterns of U.S.Academic Librarians from 1998 to 2002," College and Research Libraries 67, no. 3 (2006): 205-16.

55. Moriarty, "Academic in Deed," 17.

56. Pamela S. Bradigan and Carol A. Mularski, "Evaluation of Academic Librarians' Publications for Tenure and Initial Promotion," The Journal of Academic Librarianship 22, no. 5 (1996): 360-65.

57. David L. Groves, “Criteria for Tenure and Promotion Decision,” Education_111 (1989): 162-68.

58. Gloriana St. Clair, "Research and Respect," College and Research Libraries 56 (1995): 297-98.

59. Alexander Serenko and Nick Bontis, "A Follow-up Ranking of Academic Journals," Journal of Knowledge Management 13, no. 1 (2009): 16-26.

60. ACRL, Joint Statement of Faculty Status of College and University Librarians. Available online at www.ala.org/ala/mgrps/divs/acrl/standards/jointstatementfaculty.cfm. [Accessed 23 September 2009].

61. Judith F. Krug, "Intellectual Freedom and ALA: Historical Overview, " in Encyclopedia of Library and Information Science. 2nd ed., ed. Miriam A. Drake (New York: Marcel Dekker, 2003), 1379-89.

62. Hill, "Wearing Our Own Clothes," 74.

63. Richard L. Hart, "Scholarly Publication by University Librarians: A Study at Penn State," College and Research Libraries 60, no. 5 (1999): 454-62.

64. Jerry D. Campbell, "An Administrator's View of the Negative Impact of Tenure on Librarians," Technical Services Quarterly 6, no. 2 (1988): 5.

65. Gail Wood, "Academic Original Sin: Plagiarism, the Internet, and Librarians," The Journal of Academic Librarianship 30, no. 3 (2007): 237-42.

66. Michelle Martinez, "Life as a Humanities Librarian," Biblio-Notes 53 (Spring 2009): 5.

67. Gail R. Gilbert, "Keeping the Bar High: The Reinstatement of Tenure for Librarians at the University of Louisville," Kentucky Libraries 71, no. 2, 1961: 17-19.

68. AAUP, Statement on Collective Bargaining. Adopted 1973, revised 1984. Available online at www.aaup.org/AAUP/pubres/policydocs/contents/statementcolbargaining.htm. [Accessed 25 June 2009].

69. Jane Fogotson, "A Staff Librarian Views the Problem of Status," College E Research Libraries 22, no. 4, 1961: 275 .

70. American Association of University Professors, "Incentives to Forgo Tenure." Available online at www.aaup.org/AAUP/issues/tenure/forgoincentives.htm. [Accessed 22 June 2009]. 